\title{
Futebol para Deficientes Visuais: Football 5-A-Side
}

Gustavo LEVANDOSKI ${ }^{1}$

SOUZA, R. P.; CAMPOS, L. F. C. C.; GORLA, J. I. Futebol de 5: fundamentos e diretrizes. São Paulo. Editora Atheneu, 2014. 81p.

Editado em 2014, o livro organizado por Souza, Campos e Gorla tem o apoio do Comitê Paralímpico Brasileiro, e pretende transmitir a experiência profissional dos autores baseado em vivências práticas deste esporte, a fim de contribuir no fomento e crescimento do Futebol de 5 em nível escolar e acadêmico.

O livro é composto por nove capítulos e redigido em linguagem clara e objetiva, sendo acessível a estudantes ingressantes em cursos de formação profissional. O primeiro capítulo é dedicado a descrição de aspectos gerais da deficiência visual como característica anatômica e etiológicas, além da descrição sobre o padrão de crescimento, maturação e desenvolvimento motor destas pessoas. No segundo e terceiro capítulo os autores descrevem sobre o surgimento, evolução e principais regras deste esporte. Os capítulos seguintes enfatizam diferentes peculiaridades sobre os fundamentos técnico/táticos, análise do jogo, lesóes esportivas, avaliaçáo física e as diretrizes para execução prática do jogo propriamente dito.

Esta obra é de extrema relevância para o profissional de Educação Física, principalmente ao professor que atua na educação básica. Não apenas pelo enriquecimento teórico, mas como ferramenta didática no planejamento de atividades de ensino, incluindo um ambiente não restritivo.

A partir de reflexões que vão da história até evolução dos aspectos técnico da modalidade, permite ao professor explorar, criar e adaptar materiais esportivos para serem utilizados com alunos sem deficiência quando o professor não estiver em posse de uma bola com guizo.

Outro aspecto positivo que contribui no fomento desta temática é a escassez de publicações voltadas para a compreensão do esporte em si. Em outra obra semelhante "Esporte Paralímpico" (MELLO; WINCKLER, 2012) o capítulo 13 é dedicado ao Futebol de 5, que apresenta sucintamente sobre alguns aspectos deste esporte, mas que deixa grandes dúvidas na compreensão de pequenos detalhes das principais regras do jogo que são claramente apresentadas nesta proposta.

${ }^{1}$ Professor Adjunto ao Colegiado de Educação Física da Universidade Federal do Vale do São Francisco-UNIVASF. Petrolina-PE, Brasil.glevandoski@gmail.com 
Alguns pontos fracos podem ser levantados, mas que não desmerecem a qualidade da obra. Em futuras ediçóes os capítulos de números 8 e 9 poderiam apresentar uma discussão mais densa sobre alguns aspectos: As principais lesões são musculares ou esqueléticas? A maior incidência de lesão está ocasionada por fatores intrínseco ou extrínseco? Qual o segmento corporal apresenta maior incidência de lesão? No tópico seguinte (avaliação física), fica evidente uma divergência dos testes motores utilizados neste capítulo em relação aos estudos apresentados no primeiro capítulo. Tratando-se de uma temática em crescimento e com pouca produção científica, a divulgação de tabelas normativas para fins comparativos merecem cautela em virtude de procedimentos estatísticos de confiabilidade das medidas.

Em síntese esta obra exprime informações relevantes por reunir argumentos científicos, associado à experiência profissional de seus autores, que contribuem significativamente na difusão deste esporte pouco explorado academicamente.

\section{REFERÊNCIAS}

MELLO, M. T.; WINCKLER, C. Esporte paralimpico. Atheneu, 2012. 